\title{
An English Promotional Video to Show the Well-Rounded Students of Pelangi Kristus Children Seminary
}

\author{
Saefulloh, M. \\ English Department, Faculty of Letters, Petra Christian University \\ Siwalankerto 121-131, Surabaya 60236, East Java, INDONESIA \\ E-mail: sam92muhammad@gmail.com
}

\begin{abstract}
Pelangi Kristus children seminary is a Christian school which runs its educational levels from kindergarten to high school whose curricula and teaching principles are based on biblical perspectives. The competitors of this school are also Christian schools that exist a few meters away, in the same area. Its main problem is the ineffective video that this institution utilizes as a promotional means. To alleviate its promotional video problem, creating one- and two-minute videos which emphasize on independent learners and social excellence are the best solution since this school never makes any short videos that can rebrand its old images. As a result, this company will have such a fresh positive image.
\end{abstract}

Keywords: Well-rounded students, English promotional video, and rebranding.

\section{INTRODUCTION}

Pelangi Kristus Children Seminary is a Christian school which was established in 1996, initiated by a faithful Christian who has been called by God as a Christian educator. Located in Jemur Andayani XXII/4, South Surabaya, this school structurally opens its educational levels from kindergarten to high school. Students of this school are typically devout learners who seek for a consistent biblical- and science-related education. Its learning activities usually run from Monday to Friday at 8 a.m. to 4 p.m. There are two main competitors of Pelangi Kristus in which they have already established before it existed. Basically, its competitors are located a few meters away, in the same area. They are also Christian schools. As Christian schools, they are concerned with vision and mission whose biblical values label themselves as a Christian organization. Next, the promotions that they create have advanced considerably over recent years. It is not surprising that they are wellknown among Surabaya people. Lastly, they indeed know how to utilize a promotional video. To get more customers, the promotional videos that they produce contain good selling points such as academic excellence, good accreditation, winning competition, and excellent facilities.

Speaking of Pelangi Kristus' problems, the school has three different problems, but there is one remaining problem which is worthy of a solution: its ineffective promotional video. Technically, the school produces its promotional video into ten minutes in length and always gives it to new customers. If it is seen from marketing perspectives, a promotional tool, especially a promotional video, should be concise and no more than three minutes in length; the content of a promotional video has to reach customers' needs. In terms of efficiency, the available promotional video this school utilizes is slightly effective to get customers' attention since there are too much unneeded information that the school can keep and share them later when its new customers are already members of it. Considering the fact that the school has never utilized a short effective promotional video, the two- and one-minute English promotional video is going to solve its ineffective promotional video.

Three reasons of the English promotional video will be really effective to solve its ineffective promotion. First of all, the English promotional video can be a goodwill message to deliver what Pelangi Kristus wants to communicate. This English promotional video will function as bridge- 
building that addresses a number of misunderstandings. This can happen because the contents of the English promotional video videotape the students' activities showing them to be well-rounded learners. Needless to say, this promotional video will start taking its footages from the early school to its advanced school. Taking footages are needed in order to ease everyone watching it in understanding its storyline. As a result, its prospective Christian parents will change their attitude towards it after watching the new brand of promotional video. Second, the English promotional video will be a permanent marketing tool for this institution. After having done the work of creating the video, there is usually a copyright that protects it from illegal distribution. Because this work is one of the academic requirements from the university, the finished work is going to be given to Pelangi Kristus permanently. In other words, Pelangi Kristus can use it freely without any hesitation in maximizing it as a marketing tool. Most importantly, the English promotional video is portable. Unlike the former promotional videos, the new video is not going to be stored into compact disc or digital videodisc anymore. It is also user-friendly because it is short and directly gets to the points Pelangi Kristus needs to deliver. Aside from being user-friendly, this promotional video supports social platforms such as Whatsapp, Line, Instagram, YouTube, Twitter, and so on. Therefore, Pelangi Kristus only needs a smartphone or other smart devices which can support the video and share it with others.

\section{PRINCIPLES FOR DESIGNING NEW PRODUCTS}

In creating the English promotional video, there will be six different subjects that are related to one another: branding and rebranding, USP, digital marketing, video production, promotional video, and color.

\section{Branding and Rebranding}

Prior to defining what rebranding is, it is vital to know what branding is because branding comes at first. Fachruddin (2016, p. 85-86) defines branding as an effort that should be created to develop a positive image. Also, he postulates branding as a communication tool to promote a company's product and service in an attempt to face a challenge and a change in the marketplace. In addition, when branding mostly deals with creating good images, rebranding is as a further step of repositioning, re-strategizing, or re-picturing better images. Rebranding also means to refresh an old brand that needs to renew. Therefore, rebranding can also function effectively in facing up to customers' attitude towards the advancement of technology and information (Fachruddin, 2016, p. $85-86)$.

\section{Unique Selling Point (USP)}

Purposefully, USP is a marketing strategy development which tries to understand customers' needs. Creating USP should be clear so that it will identify properly the targeted customers. USP functions to increase the perceived value of products or services. Consequently, it makes them worthy of selling point (Chapman, 2008, p.64-65).

\section{Digital Marketing}

According to Sreedharan (2015), digital marketing is a promotion of a company's products, services, or brands which uses one or more forms of digital or electronic media. Then, Doyle (2016) adds digital marketing as the use of digital technology both web and multimedia, in which its processes entail development, distribution, and promotion throughout internet such as website and e-mail as well as other digital media: wireless or mobile. Living in the advanced internet era, the use of internet is a reality that cannot be avoided. Naturally, people especially children starting from primary to high school are accustomed to exposing themselves to the use of internet. They learn how to use the internet by exploring it themselves, not to mention by being taught at a school (Budiargo, 2015, p.12). The use of internet is more extensive for not only exchanging information, but also experiencing advantages such as a medium of a social media (Facebook), an email delivery system intended for school's assignments, etc. (Susanto, 2017, p.1-2). Knowing the fact that people living nowadays have a strong interest in the power of the internet whether it is used for exchanging information or seeking more benefits, digital marketing has a big important role in shaping modern 
life. However, there are several reasons of digital marketing that make it important: effective, reliable, and easy. The first thing to look for is that the digital marketing is effective. When living in the past, people wanting to promote a product, they often used a radio to broadcast the product, or even a newspaper to post it in paper form, usually printed in a small column in a newspaper. Today, due to high cost and impracticality, people progressively start to leave traditional marketing that happened in the old era, so a simple short video that can capture uniqueness of a product can be chosen (Politwika, 2015, p.91). Next, it is truly reliable. Talking its reliability, internet has given a huge number of advantages for its users; $76 \%$ businesspeople use social media to market their products (Politwika, 2015, p.10). Last, it is definitely easy. A digital consultant reported that social media can help broadcast news or videos to go viral (Politwika, 2015, p.11). Thus, looking at both terms, digital marketing and social media, especially digital marketing is important to make a thing known virally.

\section{Video Production}

Making a video does not simply involve a camera to roll and to take some footages; however, there is one thing that makes a video valuable: a script. A script is like a plot to deliver the product's messages effectively. Three elements should be attached in the video: strong intro, images reinforcing messages, selling information at the conclusion (Johnsen, 2017, p.292). In other words, a script as stated by Johnsen, functions as a technical thing before production gets started. Diefenbach (2009) gives a very simple meaning of video production. He writes that the video production is an art, science, and business. Technically, video production is aimed at non-broadcast program-making. Millerson (2001) adds that video production is different from television production. Video production is often recorded closed-circuit on videotape, distributed and viewed by a small audience. Despite being produced by closed-circuit, it is undeniably made with excellent equipment ranging from the most sophisticated professional broadcast standards, to low-cost consumer items and economically budget programs for particular audience sectors. Furthermore, video production is an effective means to promote something (Owens, 2017, p.1). He simply cites YouTube as an example - it is a platform that supports a million videos intended for many purposes which can answer every single audience's need. Everything now is being done digitally. Since videos are aimed at manipulating audiences' responses and emotions, the main purpose of creating videos is to trick audiences to get involved in it. Video and television are reportedly a means for Americans to get information and entertainment. This constant habit in finding out information and entertainment leads to a massive video production (Wolsky, 2004, p.3). Speaking about video production, one thing that should be considered producing a video is a promotional video. Again, quoting what Millerson (2001) has said, since both of those things deal with processes and techniques of video making which end up being marketed, a promotional video constitutes production processes of a certain film or commercial with implicit purposes of promoting the advertised film or the product advertised in the commercial.

\section{Promotional Video}

Promotional video is intended to disclose aspects related to commercial. (Norris \& Meier, 2014, p.395). Producing a video to promote a business was not a good choice in the early 1980s, but it changed dramatically three years later at the same period of 1980 s to the $21^{\text {st }}$ century. This was caused by the power of money that could benefit a recording company. People working at an advertising company began to realize that promotional videos could benefit them by selling their products. Moreover, when artists such as actors or actresses, singers, and models became idols their fans, the promotional video intended to rate whether a company or the artist constitutes a valuable product. At that moment the company whose business runs in digital promotion created a royalty system (Thall, 2016, p.33-34). YouTube at least becomes one of the most popular platforms to watch a billion videos. Blundell (2015) reports that online videos are growing so fast that have reached 1.5 billion in 2016 and with prediction that $74 \%$ of internet traffic will be video by 2017 . As a result, videos are getting more and more consumers' attention and hours of watching. It is no surprise that then companies take this phenomenon to market either their products or services so that they can gain advantages. Blundell (2015) also notes that there are five reasons why video is fundamentally becoming attractive. First, videos create more 'buying ready' costumers. When the company's videos 
are ready to get marketed virally, the videos can drag customers to have confidence in buying the products or services after watching them. Second, videos create more engaged customers. Watching videos is easier than trying to read the text; this therefore leads to the engagement of customers' visual and auditory senses, giving them a more stimulating experience for brands. Third, videos can accomplish more in less time. Videos are undeniably a tool that can convey more complex, intricate and nuanced messages. Fourth, videos are great for search engine optimization (SEO). SEO is the art of getting the website to rank higher in Google's search result, so when the customers searching for any product it can directly drag into the products being sought. Fifth, videos are easy to share. Since it is formed into softcopy, videos can be shared easily, not to mention mobile friendly. As a part of digital marketing, a promotional video is made based on the production of digitized processes that comes from graphical vehicles, intended to distribution towards selective audiences. The next section will construct stages in producing the promotional video.

\section{Stages in Producing the Promotional Video}

Cartwright (2012) mentions three principles in producing a video: pre-production, production, and post-production. Thus, this part is going to deal with an explanation of these three principles. Pre-production mostly deals with preparation for all steps required to execute the production and post-production. The pre-production is truly decisive because the following steps rely upon it. The first step to pre-production is a need for assessment; meaning that a good analysis will accurately describe problems and appropriate solutions. The most important thing in this step is to be clear and concise so that it will lead to a good statement of problems and proposed solutions. Apart from that, budget development is something that needs to be considered since there are many vehicles involved in creating this video production, not to mention the crews. Furthermore, this part involves the process of content organization, scripting, visualization, equipment, crew, talent selection, graphic planning for the actual days of the shoots, and planning for editing (Cartwright, 2012, p.14-15). Production consists of focusing the attention on the equipment operation and working crews and talents. At this point, the focus is on energy and resource into obtaining the best possible performance with the best possible technical quality of sound and picture. The attention on the details of the shoot, the organization effort, and attention to the script come together at production, so devoting attention to performance is decisive. In addition, good pre-production can set the video maker free from burdensome details of production and let him concentrate on talent performance (Cartwright, 2012, p.19). Post-production, according to Pelletier and Muir (2017), generates a final destination of producing a video. This stage consists of editing, choosing good music for its background, and putting in a narrator voice. Finally, after passing a long process, the video should undergo one final process; that is optimizing the video either for the web or social media (Pelletier \& Muir, 2017, p.64-71).

\section{Elements of the Promotional Video}

Smith and Miller state that the major element in the promotional video is a call to action (2013, p. 257). This means that the one creating the video should ask: What should viewers do after watching the video? Email it to a friend? Order a DVD? Click for more information? Just as in direct mail or email marketing, the goal in this strategy is to convert viewers into buyers. Most importantly, the video has to be informative, interesting, and short. A video that is under three minutes is the best video that should be considered. The one making the video should think that he or she is in the position of the viewers watching the video. Because of that, it is often made no more than three minutes to avoid tediousness. The video should be humorous, awe-inspiring, educational, entertaining, unique, evocative, and controversial. In addition, specific videos that reach out targeted customers have to be determined, and one of intended specific videos is a testimonial video. A testimonial video is basically an unpaid person who gives a speech to express his or her idea about the satisfaction they feel towards products or services being used, and the one giving the speech need not be polished (Smith \& Miller, 2013, p. 257).

Color

Color is an important part to make an artistic work more alive (Eldridge, 2007, p.12). He gives such a clear definition concerning cool and light colors. 
"Resulting in shooting, calming, meditative and peaceful perception, cool colors are basically anchored in blue which then forms various colors from green through blue and violet. Meanwhile, light colors are translucent which reflect light with a subtle illumination, making it larger and airier".

Furthermore, According to Zeembry, Martin, and Baba (2013, p.111-115), a green color has its psychological relation to nature. It also depicts calmness, growth, freshness, and hope. Cool colors which are in the green-blue spectrum can calm and reduce nerves.

\section{PRODUCTS AND RATIONALE}

There are three divisions to understand the tool's justification in which some of divisions are going to be supported by the theories that have attached in principles for designing new products section. Hence, in realizing the English promotional video which will reach its desired targets, such components are analyzed as follows:

\section{The Content}

To make this part clear, there are going to be five contents in which each content comes up with its rationale. First of all, I have made two types of promotional video: two- and one-minute videos. Fundamentally, the promotional video I have made aims to promote Pelangi Kristus' wellrounded students, so it has to show aspects of a commercial (Norris \& Meier, 2014, p.395). The choice of specific duration for the video is as an attempt of preventing boredom when its viewers watch it (Smith \& Miller, 2013, p.257). Furthermore, the two-minute video is going to be distributed to various social platforms such as YouTube, Whatsapp, Line, Facebook, etc. The reason for choosing such social platforms is because the school utilizes them to connect with its parents. This school has already attached their old videos into YouTube, so the English promotional video is going to be uploaded to that social platform which hopefully reach out a huge number of viewers (Blundell, 2015). In addition, the two-minute video consists of narrator voices and testimonies given by five active students and two alumni of Pelangi Kristus. I think the two-minute video is an educational, unique, and awe-inspiring video since it is made to provoke its viewers so that they think about right education (Smith and Miller, 2013, p.257). The one-minute video only consists of narrator voices. Thinking of avoiding repetition, I created the promotional video differently. Other than that, the oneminute video is for Instagram, in which this social platform can only upload a file no larger than fifty-nine second. By attaching the videos I have made to such social platforms, it will engage parents' visual and auditory senses and they will later spread the videos to their relatives (Blundell, 2015).

Secondly, I chose a guitar instrument for its musical background using a popular Christian song, 'Pekerja Kristus yang Mulia'. Initially, the instrument plays at its opening so that its viewers will not get shocked. I think the reason to put it first is to soften its viewers' psychology, so they can follow the videos easily (Wolsky, 2004, p.3). The reason I used the guitar instrument, not other complex instruments, is that it is rare and entertaining (Smith \& Miller, 2013, p.257). Most of promotional schools' videos I have watched utilize complex instruments such as piano, violin, drum, etc. Those promotional schools' videos are likely to create such great images so that viewers will think they are great schools. On the other hand, the utilization of its simple instrument underlines an awe-inspiring message (Smith \& Miller, 2013, p.257); that being simple does not mean lacking in beauty and being weak. In fact, the instrument was played by a student who is waiting to start a music degree that will be taken after graduating from this school. This fact can later counter such prejudice towards this institution. Furthermore, the Christian song that is used for its background is a popular song, but it is legal, not a copyright work, since it is re-played by its student. Regarding the theme of the chosen song 'Bukan Sembarang Pelayan', there is one message that I want to highlight. This institution is viewed as a creator of pastors or church full-timer; as a matter of fact, it is not. That this school creates one specific profession is not fully right, yet it has been freeing its students to choose whatever professions as long as they stick to God or they serve Him in the profession they enter.

Thirdly, I used English as a communication medium in this video. I considered using English in this video because English is more powerful to grab viewers' attention. People are more interested to watch English channel these days giving many reasons like it is cool, academic, smart, or even 
practicing language to increase proficiency; therefore, creating the video into English actually manipulates audiences' responses and emotions (Wolsky, 2004, p.3). If customers have already thought the school is good due to the English, it will then create buying ready customers (Blundell, 2015). In the end, English gets much attention from its viewers.

Fourthly, I decided to use five active students and two alumni of Pelangi Kristus since I think testimonial videos empower unpaid people (Smith \& Miller, 2013, p. 257). I chose five students and came up with four girls and one boy since they are excellent, let alone their English ability. On top of that, the head of human resources and administration agreed with my proposal of the chosen students. He said that they earned a good reputation by becoming the type of students that this school expected by showing excellence in academics, attitude, and social areas. More than that, they were appropriate because they were not in preparation classes of national examination, so I could work well with them without any hesitation. Furthermore, the reasons of choosing two alumni would be an answer of many doubts concerning a specific profession: a pastor or a church full-timer. In fact, the first alumnus has just graduated from two universities majoring in literature and film, and has worked in a field related to her degree. The second alumnus is currently studying and will graduate in August. Actually, there are a lot of excellent alumni beside the two alumni I used. However, they were not all available in Surabaya. I was suggested to make a phone video, but I think the result would not be as good as using a professional camera. I had no doubts over two alumni used in my video because I consulted with the head of HR and administration and the head of junior high school who is a parent of one alumnus before the execution took place. Again, the head of HR and administration said that they were good in terms of representing an image of the school. He knew that one has graduated from two universities, and another one developed such excellent selfendurance when studying at this school. For that reason, he agreed with my two chosen alumni and made me ready to start the video's execution.

Lastly, I used cool and light color for the English promotional video. The two different colors that I chose emphasize on softness (Eldridge, 2007, p.12). He states that cool and light colors are to calm and meditate. The idea of softening the colors of the video is that its viewers will probably not be young people. There can be senior citizens which will be bothered if I create it using very bright colors. A green color has a psychological relation to nature which creates calmness, growth, freshness, and hope. Also, I think the soft colors match with the guitar music since the cool color has a green-blue spectrum which can calm and reduce nerves (Zeembry, Martin, \& Baba, 2013, p.111$115)$.

\section{The Order}

Putting into sequences in the previous order part, it will come up with deeper analyses of the video's arrangement in this section.

To begin with its opening, a guitar instrument and footage of Pelangi Kristus's logo open its first scene. The choice of the guitar instrument that comes first is as an attempt of affecting viewers' psychology so that they will not get shocked when watching it. Then, the footage of its logo demonstrates the identity of the school's name so that the viewers will know it exactly. Following this, the narrator voice takes place by saying, "We are Christian school which has strong biblical values". It is then followed by footage: a teacher ordering students to queue and pray. The reason of the statement uttered by the narrator shows its strong thesis that this school consistently applies for a biblical paradigm, which is then supported by the footage of the teacher leading the students to queue and pray. Strengthening this point, this school in fact obliges its students to be faithful in doing small tasks before getting into the class: queue and prayer. By internalizing this value, students are expected to discipline themselves so that they grasp the fundamental core of Christian education, which have to start with discipline, and will deliberately apply that fundamental value in their entire life.

After that, the narrator says, "Every student in this school is equipped to either be a Christian leader or to be a servant of Christ with Christ-like character". The footages in the second step are kindergarten students giving a gift for a security and shaking hands with local people. Examining points in this scene, it is then really important to realize that biblical values have to be implemented in school life. Both arguments and pieces of footage underline biblical values since equipping students to have Christ-like character and doing good deeds are equal to making alive those values. 
By doing so, they will have indeed stored magnificent valuable teachings in their hearts. To prove this principle, Pelangi Kristus has certain social activity that constitutes part of its fixed agenda. I found out this fact when I did the internship. After all, this scene emphasizes on the important issues of how this school animates such high values.

Next, a young student coming from kindergarten says, "I am happy to be here", and it is then followed by a background of other kindergarteners. This scene is actually a continuation of a step on how it implements the magnificent principles. The happy sentence and his joyful expression are actually from his heart. It is said when he was interviewed to be the first actor and willingly trained to have such impromptu action. It is for this reason that the sentence of "I am happy to be here" was brilliantly born. Also, the happiness depicted in his statement is because of real social activities that this school sets up. By setting up this situation, students experience such real learning experiences happening both inside and outside the classes.

Then, the narrator speaks, "We have been consistently preparing students to find God's calling for over fifteen years". The footages for this step are a female student giving a salutation, a male student pledging over a bible, and a female student starting with her lesson book. I created this screen combined with footages because of Pelangi Kristus' consistency in running its biblical principles. I assumed no Christian school would so dependably apply such principles. After that, the consistency is then answered by an elementary student who says, "Me? No doubt anymore! This expression states certainty that education has to free somebody from being chained; being chained from many unreasonable principles and irresponsible teachers. As a result, the expression indicates that the school provides true and reliable education.

Following to the previous paragraph, the narrator speaks, "For us, teaching students to find what they want to be in life is not sufficient". The footages for this step are a supervisor teaching a student and an elementary student putting charity goods together. In the first footage, I consider it as an attempt of creating independent learners; meanwhile, the second footage is social excellence that the school has. I think two principles, independent learners and social excellence, become an excellent method because such good selling points are applied intensely. Further proof that I believe strengthens this point, an elementary student saying, "I am here to find God's purpose". It is closed by a statement from the narrator, "But training them to be learners who know and put their trust in God is truly worthwhile". The following footages are an elementary student working on a daily lesson, a student seeking for a verse in a bible, queuing, two girls teaching and a female student doing her task. In my opinion, finding God's purpose is back to something that reveals His revelation. The footages of working on daily lessons and seeking for verses in the bible show that those things are interconnected. If the interconnection is found, students will learn from what they have discovered faithfully. It is shown in the same footages that portray: students queuing, two girls teaching and a female student doing her task. Simply, this school trains its students to always search for an answer if they need something. I found that students are well-prepared to pursue their desires after they graduate. When I asked some students how sure they were, they answered confidently and humbly that they found out and set up their dreams based on the living words, for they always found the right navigation in the word of God. Finding God's purpose and training students to trust God are the highest purposes of education since training results the greatest achievement.

Creating the greatest result is also shown in the following statement, "One of the best school in my life is when you are taught to know God", says a girl student, and it is followed by footage: students and supervisors attending a flag ceremony. For me, knowing God means loving the country where they live in. Both statement and footage, a school teaching to know God and being followed by the flag ceremony, are a clear teaching; there is no contradiction between them. I highlight it as social excellence. I believe that God teaches people to honor the country and government because they are representatives of God in the world. I once interviewed the head of senior high school regarding the flag ceremony this school does. She directly answered that this school never wanted its students to forget Indonesia as a country where students grow up and receive further education. As for the head of senior high, most of its graduates pursue overseas degrees after graduation and stayed longer in the country where they studied. For that reason, there is always the emphasis upon God and Indonesia so that they will love and return to Indonesia.

Then, the narrator speaks, "We educate students without comparing them to each other because we strongly believe that children are created uniquely". The footages for this step are 
students waving a red-white flag, and a girl student pledging over Christian and Indonesian flags. Education without comparing means that every student in this school has the same opportunities to raise such flags the school honors. As stated in the pledge of flags they always raise, the students are taught to appreciate diversity, to serve others and Indonesia, and to love God's creations. As a result, there is no comparison to one another.

Later, a female student says, "The word of God and science are the most perfect combination". It is followed by a performance of a female student entertaining the needy. I chose the same person in this scene because I want to underline that the Godly words and the performance are relatable. I remembered supervising a drama class near Christmas. Students were busy for drama rehearsal. They would perform in front of their outreach children so that they could share love with them. Not only did they perform, but they also taught those needy children to have a better understanding about life. I think the word of God here is like a theory that students learn in every aspect of lessons in the school while the science is a practical matter after learning such theories like drama class. They learn how to serve and love others through lessons they learned. In the end, what they have done, the drama performance, is actually an integration between faith and science.

A graduate from this school who is currently studying in the English department of Petra Christian University says, "Pelangi Kristus equips me to excel not only in the academic, but also in the community. I think the best education is when you are free to be who you want to be". The footage for this step is a group of students who are teaching and learning in a regular outreach. I attach this scene because I want to show that this school excels in two things; academic which creates independent learners and social which makes students mingle with society. Also, a graduate from this school and the same university that has already worked says, "Studying at Pelangi Kristus helps me deal with problems during my college study and work. I can finally now be myself who is a free learner. A free learner which is meant by this scene is that Pelangi Kristus frees its students to learn whatever lessons they like. This school therefore does not have a specific program like science and social studies. It is then captured that the graduate testifying in this scene is not chained by a limited choice. Many are afraid that this school prepares church workers, but its testifying graduate proves that she can be anything she wants. She has graduated cum laude from literature and film degrees; then, she works in a field which matches her passion. Finally, the statement coming from her is to show that this school is not what others think: a creator of pastors or full-time church workers.

The video is wrapped up by a statement of the narrator, "They have their own calling to be the agent of Christian education", and followed by footages of commencement and prayer. Traditionally, there is always a prayer-meeting day which is specifically intended for those just graduating from this school. They will be gathered to be prayed for by the founder and members of school committees. Before prayer, students thank the school as a sign of goodbye greetings and say their next schools with their specific majors. After that, they all pray altogether to bless students' choices. I think it is clear enough that their own calling to be the agent of Christian education is when they can decide what to do in life and always raise up Christian values.

Finally, then, the closing of this video is a logo of Pelangi Kristus and its address, telephone, fax and email, functioning as an indirect call for action. I once asked the founder and general manager of this school in regard to the video they preferred. Both of them agreed with a video which has no direct selling; meaning that it is unnecessary to call customers directly. They want to have a video which makes customers think of what the best education is like because they believe if customers have the same vision and mission they will match with Pelangi Kristus. As a result, the call to action I made merely consists of a statement, logo, address, etc.

\section{The USPs}

The English promotional video simply underlines the regular activities of Pelangi Kristus' students which make them well-rounded. The well-roundedness which I chose to be highlighted in this video constitutes independent learners and social excellence. Being independent learners and showing social excellence are definitely things that this school teaches the students. In its application towards the students, it really focuses on how to build an excellent personality by educating them biblically and scientifically, not to mention socially. In addition, the well-rounded topic also functions as an effort of repositioning and re-picturing the old images. Because of that, it can 
positively refresh and renew the school's images which can change customers' attitude towards it (Fachruddin, 2016, p.85-86).

\section{CONCLUSION}

The main problem of the school that I was concerned with a solution was the ineffective video. Looking at the ineffective video, I realized that this school maintains such a mistake by utilizing long duration video, usually given to new customers to learn about the school. I then thought if the school kept giving the ineffective video its new customers would end up agreeing such prejudice towards this school. To answer reasonably, I initiated myself to produce the English promotional video which contained two USPs: independent learners and social excellence. I also utilized English in my video since this school has never made any English video before. Then, I made the video into two various videos: one- and two-minute videos to avoid tediousness when its viewers watch them.

Prior to the processes of leading the English promotional video creation, I have summarized the processes into three categories: pre-production, production, and post-production. The pre-production was when I prepared everything with regard to preparation. Later, when everything was ready, the execution of working days took place which were in March to April. In the final step, the postproduction was like the finalization of scenes taken, and I finally gave the English promotional video to the school.

To make it more efficient if the company wants to utilize the English promotional video, there are certain steps to do that. First, the school should know who their target markets are. Knowing exactly the target markets will help the school get their position. I think the school has its Whatsapp group and Instagram. Those two social platforms have such good power to create buying ready customers. After the video is spread to those social platforms, I think it is important to make an introductory sentence which introduces and gives its overview so that viewers can know what it is.

\section{REFERENCES}

Blundell, J. (2015). Capture more customers with videos: The why, what, and how. Australia: Michael Hanrahan Publishing.

Eldridge, K. (2007). The complete color harmony workbook: A workbook and guide to creative color combinations. Singapore: Rockport Publisher.

Fachruddin, A. (2016). Manajemen ertelevisian modern. Yogyakarta: Penerbit Andi.

Norris, S. \& Meier, C.D. (2014). Texts, images, and interactions: A reader in multimodality. Berlin: Walter de Gruyter.

Smith, R. \& Miller, K. (2013). Shoot to sell: Make money producing special interest videos. Massachusetts: Focal Press.

Wolsky, T. (2004). Video production workshop. Massachusetts: Focal Press.

Zeembry, Martin, D. \& Baba, T. (2013). 212 tips mastering professional web design. Jakarta: PT. Elex Media Komputindo. 